Article

\title{
Pandemic Preparedness and Public Health Expenditure
}

\author{
Noura Eissa \\ Faculty of Economics and Political Science FEPS, Future University in Egypt FUE, 90th St, Cairo Governorate, \\ New Cairo 11835, Egypt; noura.eissa@fue.edu.eg
}

Received: 8 June 2020; Accepted: 22 July 2020; Published: 27 July 2020

\begin{abstract}
The motive behind this article is investigating alternative indicator measures for the effectiveness of public health expenditure on pandemic preparedness, to explain the reasons behind country variations in containing crises such as Coronavirus disease 2019 (COVID-19). The purpose is to analyse the shortcomings in the relationship between global public health expenditure and pandemic preparedness. The research methodology includes a macro-analysis of global health spending patterns, empirical and theoretical literature on global health expenditure, global health security indexes, and country case studies pre- and post-crisis. The results show that gaps in pandemic preparedness were already existent pre-COVID-19, calling for a new mind-set in the way public health expenditure is structured. Healthcare sustainability indicators should transition from traditional measures such as economic growth rates, public health expenditure rates, revenue coming from the healthcare sector, and rankings in the global health security index, to new awareness indicators. Public health expenditure, a facilitator of pandemic preparedness, coupled with the resilience of healthcare systems, could be used in conjunction with the traditional factors, along with the time element of a quick response to pandemic through preparedness schemes, the progress towards achieving sustainable health through the implementation of the United Nations Sustainable Development Goals, and investment in national healthcare capital to ensure efficient resource allocation. The policy recommendations are the restructuring of public expenditure to expand the absorptive capacities of healthcare institutes, eventually leading to sustainability and universal health insurance.
\end{abstract}

Keywords: global health security index; public spending; sustainable health; resilience; corona virus; case studies; public policy

JEL Classification: H10; H12; H51

\section{Introduction}

Coronavirus disease 2019 (COVID-19), a type of coronavirus that arose in early January 2020 in Wuhan, China, not only caused a global pandemic, but also uncovered the global unpreparedness of healthcare systems. Being unprepared to absorb the overload of COVID-19 patients in emergency rooms and intensive care units, owing to safety regulations required for social distancing, hospitals and clinics were forced to reduce in-person clinic visits and surgeries by $50 \%$ worldwide, which led to a reduction in revenue from surgeries higher than the revenue coming from emergency rooms and intensive care units (Grays 2020). In turn, the reallocation of healthcare physicians and nurses with no training or practice in emergency medicines to emergency departments to absorb COVID-19 patients left them with high levels of stress and burnout, forcing some to retire early or look for alternative settings (Grays 2020). 
The purpose of this article is to investigate the reasons behind country variations in containing crises such as the COVID-19 outbreak by analysing the shortcomings in the relationship between global public health expenditure and pandemic preparedness. The results show that the gaps in pandemic preparedness already existed pre-COVID-19, calling for a new mind-set in the way public health expenditure is structured. Public health expenditure, a facilitator of pandemic preparedness, coupled with resilience, should be evaluated using both traditional measures such as real gross domestic product (GDP) growth rates, healthcare expenditure, and healthcare revenue, along with new awareness indicators such as the time-responsive element of pandemic preparedness schemes, efficient resource allocation of capital investment in healthcare equipment, and the integration of the Sustainable Development Goals (SDGs) into the plan.

The 2030 Agenda for Sustainable Development or, interchangeably, the Sustainable Development Goals, are the platform premises of the Millennium Development Goals with a target of fostering sustainable improvement in equity to meet the needs of the disadvantaged, including women, children, and the poor (Ke et al. 2011). Sustainable health and pandemic preparedness are focal targets of sustainability within the SDGs to be achieved by 2030. SDG3 ensures healthy living by promoting wellbeing for all, at all ages, under the oversight of the World Health Organization (WHO), and is integral to the other 16 goals.

\section{Materials and Methods}

At the macro-analysis level, the methodology involves a set of integrative processes: (1) analysing empirical literature and global spending patterns on health pre- and post-COVID-19; (2) proposing scenarios for restructuring public health spending to build preparedness and resilience in healthcare systems for the achievement of SDGs; (3) analysing country-specific case studies; and (4) offering policies and recommendations.

The data are based on previous empirical results, theoretical frameworks, statistical data, and country-specific case studies from reliable research papers; reports from the World Health Organization, United Nations (UN), and World Bank; previous empirical studies on public expenditure and pandemics; the Global Heath Spending (GHS) Index; and recent articles written during the COVID-19 era. Figure 1 gives a summary of the relational framework of the paper.

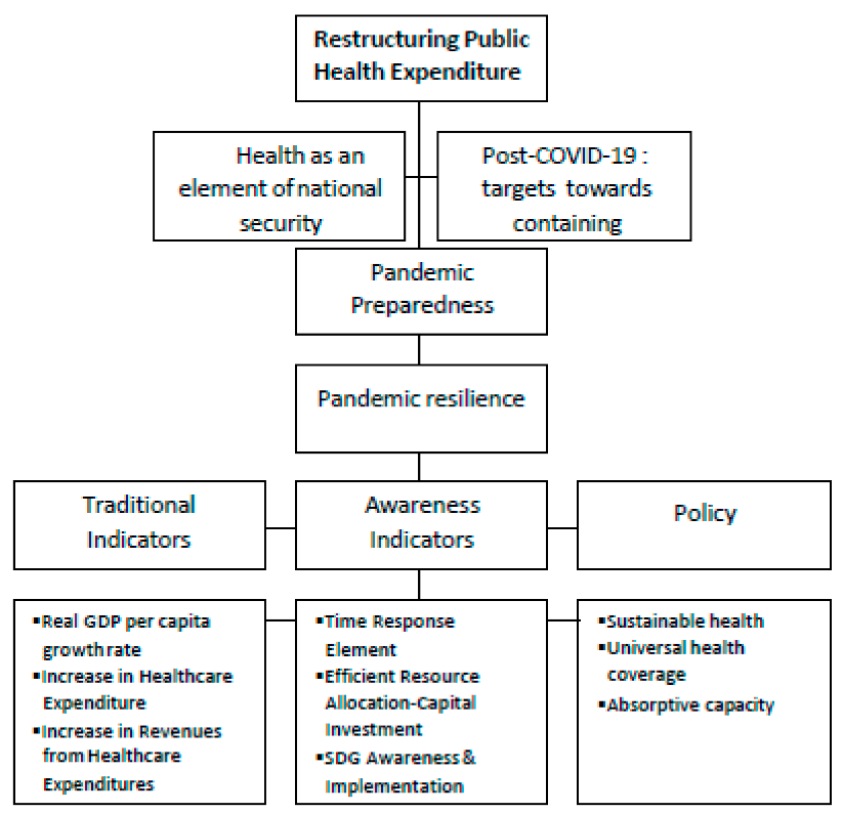

Figure 1. Relationship methodology framework for pandemic preparedness. Source: the author. GDP, gross domestic product; SDG, Sustainable Development Goal. 
Three different approaches in dealing with the COVID-19 pandemic are discussed in this paper:

1. Countries that experienced a delayed response in terms of their reaction to COVID-19. Selected countries include the United States of America and the United Kingdom.

2. Countries that reacted immediately and were able to contain the pandemic, including South Korea and Taiwan.

3. Countries that reacted to COVID-19 within the UN SDG framework, including the Netherlands and Egypt.

\section{Literature Review}

\subsection{Part A: (Pre-COVID-19): Economic Growth and Public Health Expenditure}

\subsubsection{Determinants of Public Healthcare Expenditure}

Previous cross-sectional and panel empirical studies have focused on the determinants of healthcare expenditure. Per capita GDP and income measure variations across countries in the level and growth of total healthcare expenditure. Musgrove et al. (2002) studied 191 countries and showed that health expenditure income elasticity ranged between 1.133 and 1.275, supported by Murthy and Okunade (2009), who used cross-sectional data from 2001 for 44 African countries, and found that income elasticity ranged between 1.089 and 1.121. Gerdtham et al. (1992) used a panel data analysis of Organization for Economic Co-operation and Development Countries (OECD) countries and found the income elasticity was also larger than one. Population age structure is a covariate variable, labelled as insignificant when included in regression models, explaining per-capita health spending (Di Matteo and Matteo 1998). Epidemiological needs are also incorporated as a covariate variable, insignificant in government health expenditure as a share of GDP (Bloom et al. 2010). Technological progress is identified as an important engine for the growth of healthcare expenditure, measured by several proxies of medical technological change (Newhouse 1992), proxies for cross-sectional studies at the surgical procedural level and infant mortality level (Dreger and Reimers 2005), and time proxies (Dormont et al. 2006), all concluding that technological progress is a major determinant of the level and growth of health expenditure.

\subsubsection{Empirical Evidence Relating to Health Spending and Economic Growth}

Pre-COVID-19 studies focus on relating health spending to economic growth, but fail to establish a relationship that links public health expenditure to pandemic preparedness. Primarily, the importance of public spending on health as a top priority over private spending is highlighted. According to Scherer and Devaux (2010), the longevity of private expenditure is mainly determined by public spending outcomes. In other words, public healthcare spending is a major contributor to growth (Potrafke 2010). Van Zon and Muysken (2001) introduced the Baumol effect, explaining the natural state of health sectors having lower productivity levels than other sectors, while keeping prices high to reduce volume and simultaneously raise healthcare expenditure in the long run.

Becker (1964) human capital theory questioned the efficiency of health outflows on gross domestic product, concluding that an "enhancement in health indicators could be in the long run a [driver of] GDP growth". Rivera and Currais (1999) found that the more countries spend on health, the higher their economic growth. They used healthcare expenditure per capita as a proxy for the health of people, and linked health and expansion in OECD countries from 1960 to 1990. Gupta and Mitra (2004), in a survey of 15 Indian states between 1973 and 2000, showed that per capita health spending reduced levels of poverty. Bloom et al. (2010), through studying emerging economies, discovered a direct relationship between life expectancy and real per capita income. Howitt and Mayer-Foulkes (2005), relying on Schumpeterian growth theory, linked healthcare to economic growth by focusing on the labour force injected into healthcare as a long-term economic plan. Javadipour (2005), using the generalized technique of Solow's model and inter-country panel data, showed a significant relationship between health capital, human capital, and economic growth. 
Other empirical evidence suggests an insignificant growth of public health expenditure to be an indicator of better healthcare services. A statistically weak relationship between per capita health spending, health outcomes, and per capita GDP was found by Day and Tousignant (2005) and supported by Grigoli and Kapsoli (2013), who found an insignificant relationship between public health expenditure resource efficiency and health outcomes. Both individual aggregate time series regressions and global cross section data show income elasticities of health expenditure to be greater than one (between 1.133 and 1.275) (Musgrove et al. 2002).

\subsection{Part B: (Post-COVID-19): Pandemic Preparedness and SDGs}

\subsubsection{Preparedness for COVID-19 among Global Governmental Bodies}

In context, COVID-19 has forced global governments to enforce pandemic preparedness schemes during the crisis (rather than implementing existing plans) (Gudi and Tiwari 2020). For example, China enforced a "round the clock closed management system", Italy declared a "red zone" alert, France announced a "nationwide ban on gatherings", and the USA implemented "containment areas" (Gudi and Tiwari 2020). Global governments' experiences of COVID-19 are raw, and could be described as a global rehearsal, but the experience has pushed governments to become aware of the strengths and weaknesses of their healthcare systems when hit with a crisis (Yeung 2020).

Pandemic preparedness and response capacity are the base level evidence for informed decision-making in the face of a pandemic. Chalkidou and Krubiner (2020) emphasize the importance of public government commitment to systematically strengthening health system capacity and parallel progress towards universal health coverage and global health security, ensuring pandemic preparedness and the implementation of sustainable healthcare in the context of the SDGs. According to the International Institute for Sustainable Development (IISD 2020), sustainable stimulus packages are a must, with global governments racing to fill preparedness gaps. One major gap highlighted by the COVID-19 pandemic is inequality in public health spending and distributive allocation. For instance, in advanced countries, frontline workers in service economies were most exposed to the virus, but least able to absorb its financial impact. Emerging countries with already struggling workers were not able to receive the benefits of social safety nets or stimulus packages (IISD 2020).

\subsubsection{Linking COVID-19 to the UN SDGs and Global Governments}

The 2020 United Nations report Shared Responsibility and Global Solidarity addresses the impact of the COVID-19 crisis on the SDGs, questioning whether the coronavirus has negatively affected the march of sustainability or pushed it forward. According to Mendelson (2020), Service Professor of Public Policy, there was a lack of knowledge about the SDGs before the crisis, and a lack of awareness of the world commitment in 2015 to create a more peaceful and sustainable planet. The pandemic crisis, according to the United Nations, has proven the SDG framework effective and relevant (Barredo 2020). They argue that the millennium development goals (MDGs) and SDGs "could have put us on track towards a world with access to universal health coverage and quality healthcare and more inclusive and sustainable economies" (UN 2020). The COVID-19 outbreak has enabled the world to see the dependency between inequality, health outcomes, job security, and poverty-all SDGs. According to Sarah (2020), the pandemic trajectory has reshaped the importance of awareness of the SDGs through education for sustainable development (ESD), which has been promoted for 15 years as a whole institution transformational model led by United Nations Educational, Scientific, and Cultural Organization (UNESCO).

Table 1 is a summary of the perspectives and predictions of global health economics experts on the COVID-19 pandemic. The health experts have similar insight, prioritizing the need for pandemic preparedness, mainly through efficient allocation of public expenditure on healthcare, enhancing the absorptive capacities of healthcare systems, and the nationalization of healthcare equipment. 
Table 1. Post-pandemic predictions with regards to sustainable health. SDG, Sustainable Development Goal.

\begin{tabular}{ccc}
\hline Health Expert & Problem & Suggested Solution \\
\hline $\begin{array}{c}\text { Ngozi Okonjo-Iweala, Vaccine } \\
\text { Alliance (Gavi), Chairperson }\end{array}$ & $\begin{array}{c}\text { The pandemic uncovered a lack of medical } \\
\text { equipment and supplies for testing and } \\
\text { protecting against Coronavirus disease 2019 } \\
\text { (COVID-19). }\end{array}$ & $\begin{array}{c}\text { Nationalization to produce pharmaceuticals } \\
\text { and medical supplies and a re-examination } \\
\text { of supply chain channels. Investments in } \\
\text { research, vaccines, and nonmedical } \\
\text { methods of prevention. }\end{array}$ \\
\hline $\begin{array}{c}\text { Madhukar Pai, McGill Global } \\
\text { Health Programs, Director }\end{array}$ & $\begin{array}{c}\text { There is a fear that countries that have } \\
\text { suffered huge economic losses will use } \\
\text { COVID-19 as an excuse to cut development } \\
\text { assistance for health. }\end{array}$ & $\begin{array}{c}\text { Nationalization policies to decrease the } \\
\text { inequalities in global health. }\end{array}$ \\
$\begin{array}{c}\text { Rémy Rioux, Agence Française de } \\
\text { Development, Chief Executive and } \\
\text { International Development } \\
\text { Finance Club Chair }\end{array}$ & $\begin{array}{c}\text { Public development banks are } \\
\text { overwhelmed with responsibilities to } \\
\text { finance social infrastructure as well as } \\
\text { sustain social and economic effects of the } \\
\text { health crisis. }\end{array}$ & $\begin{array}{c}\text { Construction of resilient and inclusive } \\
\text { healthcare systems to broaden the } \\
\text { achievement of SDG3. }\end{array}$ \\
\hline $\begin{array}{c}\text { Michael Eddy, GiveWell } \\
\text { Senior Advisor. }\end{array}$ & $\begin{array}{c}\text { Governments were unaware of the } \\
\text { relationship between rapid response to the } \\
\text { pandemic and effective impacts on } \\
\text { containing the disease. }\end{array}$ & $\begin{array}{c}\text { Prioritization of the efficient use of } \\
\text { resources in terms of investment in } \\
\text { healthcare equipment, research, } \\
\text { and hospitals to sustain global health. }\end{array}$ \\
\hline & Source: the author, based on Igoe and Chadwick (2020).
\end{tabular}

\section{Pandemic Preparedness and Pandemic Resilience: Before, During, and After the Crisis}

Pandemic preparedness is not a new concept, but one that has started to gain momentum. According to the World Health Organization (WHO), it is "the national response plans, resources, and the capacity to support operations in the event of a pandemic" (2020). The Centre for Disease Control and Prevention (CDC), as shown in Figure 2, divides pandemic preparedness into six intervals: investigation of the virus, recognition of transmission possibility, initiation of easy pandemic transmission, acceleration, deceleration, and preparation for future waves. Public expenditure should focus on stabilizing and gradually mobilizing the various sectors of the economy towards reopening and operating as they did prior to the crisis.

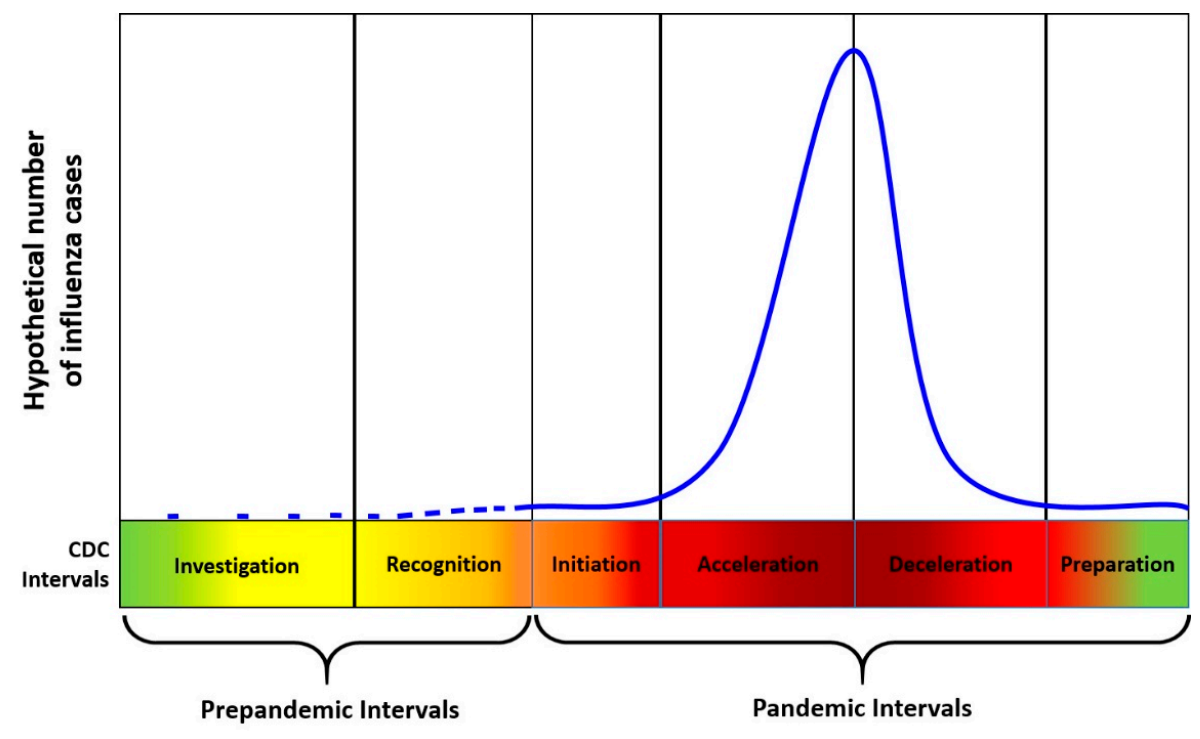

Figure 2. Pandemic preparedness and response framework intervals. Source: (CDC) Centre for Disease Control and Prevention Official (2020).

The pre-existing economy is not pandemic resilient, with its infrastructure focusing on responding to viruses rather than being prepared. The demand for pandemic resilience, a dependent and sequential variable of pandemic preparedness, has become clear. Faced with uncertainty, and contrary to human nature, resilience is critical in terms of human anticipation, coping, and adaptation to a crisis (El-Erian 2020). 
Along with pandemic preparedness, pandemic resilience is also necessary, which is "the capacity to keep the economy open while living through a pandemic through investment in capital and infrastructure (Klein 2020). Public health expenditure should be restructured to embed the four stages of pandemic preparedness and pandemic resilience illustrated in Table 2. Public financial schemes should target research to expand virus testing capacity, and sector mobility to ensure the safety of the labour force. According to the Centre for Disease Control and Prevention Official (2020), public health expenditure requires certain elements during the pandemic for pandemic resilience:

- Establishing a readiness framework through administrative processing, isolation support resources, and innovative collective organizational structures that link cities, villages, and health districts.

- Facilitating testing innovation, with scalable manual contact tracing and warning methods (with assurance of incremental increases in their production as citizens and workers start going back to mobilization).

- Expanding the absorptive capacity of disease monitoring infrastructure, technological warning applications, and testing status certificates for citizens.

Table 2. Four phases of pandemic preparedness for resilience.

\begin{tabular}{cccc}
\hline Phase One & Phase Two & Phase Three & Phase Four \\
\hline $\begin{array}{c}\text { Stabilization of essential } \\
\text { sectors by building } \\
\text { resilience and ensuring } \\
\text { labour safety. }\end{array}$ & $\begin{array}{c}\text { Relaxation of collective } \\
\text { social distancing orders, } \\
\text { with successful testing } \\
\text { programmes for workers. }\end{array}$ & $\begin{array}{c}\text { Incremental provision of } \\
\text { access to testing supplies, } \\
\text { so the government can } \\
\text { end collective } \\
\text { stay-at-home orders. }\end{array}$ & $\begin{array}{c}\text { Full mobilization of a pandemic } \\
\text { resilient economy, when testing } \\
\text { supplies support to 100\% of the } \\
\text { workforce and public health capacity } \\
\text { is sufficient to meet demand. }\end{array}$ \\
\hline
\end{tabular}

Source: the author, Centre for Disease Control and Prevention Official (2020).

\section{Traditional Indicators of Healthcare Systems}

5.1. Testing Preparedness \#1: Increases in Health Expenditure (Where Global Health Spending Growth Is Faster than Real GDP Growth) Are not an Indicator of Sustainable Health, Given the Convergence (Catch-Up) Effect of Upper and Lower Middle Income Countries

The main driver of the increase in health expenditure as stated in the literature review is either increases in GDP growth rates or increases in revenue from health expenditure, not necessarily an indicator of improvement or sustainability. Figures 3 and 4 show a converging pattern of increases in health spending between lower middle and upper middle income countries, however, large inequalities across countries remain. In the first two years of the SDG era, according to the WHO, global spending on health continued to rise, from US\$7.6 trillion in 2016 to US\$7.8 trillion in 2017, around 10\% of GDP. Public spending constituted around $60 \%$ of global spending on health, which grew on average by $4.3 \%$ a year between 2000 and 2017, but this annual growth decelerated from $4.9 \%$ in 2000 to $3.4 \%$ in 2017 . The other $40 \%$ of health funding is private, with donor funding representing less than $0.2 \%$ of the total. Between 2000 and 2017, in real terms, global health spending grew by $3.9 \%$ annually, while the economy grew by 3\% annually. As shown in Figure 3, high income countries' health spending grew by an average of 3.5\% annually, about twice as fast as the economy. Upper middle income countries converge towards higher levels of health spending, showing a rise of $6.3 \%$ a year between 2000 and 2017 , while the economy rose by $5.9 \%$ per year. Health spending in low income countries rose faster, by $7.8 \%$ a year between 2000 and 2017 , while the economy rose by $6.4 \%$.

As shown in Figure 4, health spending by high income countries represented the largest share of global spending, at $81 \%$, despite covering only $16 \%$ of the world's population, down from $87 \%$ in 2000 . Since 2000, lower middle and upper middle income countries, representing only $13 \%$ of total health spending, have consistently increased their share of global spending, reaching 19\% of the total in 2017. Highly populated countries such as India and China progressed towards higher income groups, with approximately $40 \%$ of the world's population living in low income countries in 2000 , but fewer than $10 \%$ in 2017. 


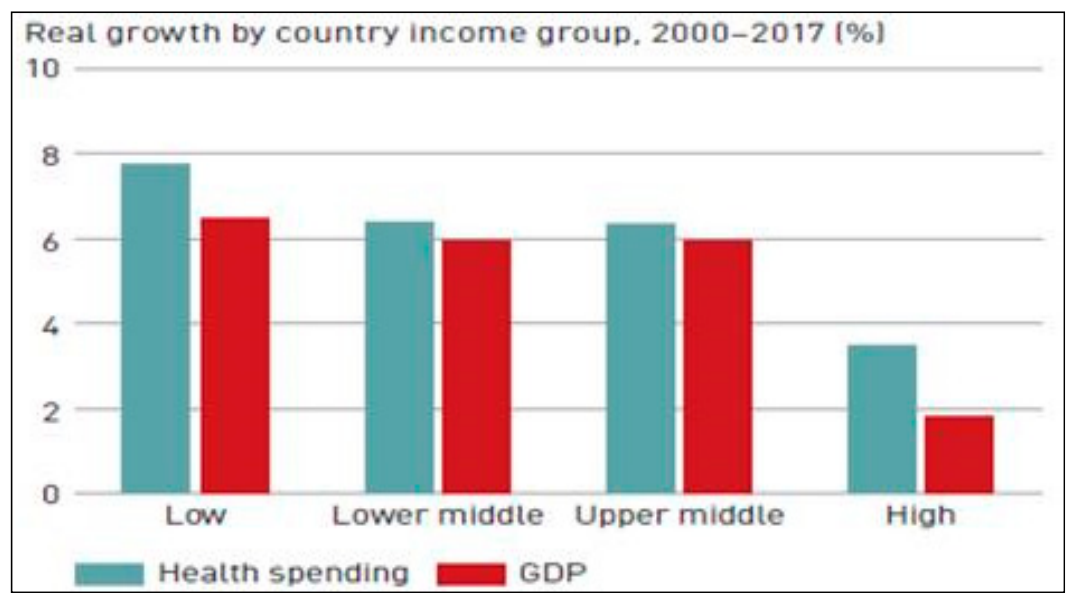

Figure 3. Health spending growth and GDP spending growth. Source: World Health Organization (WHO) (WHO 2019).

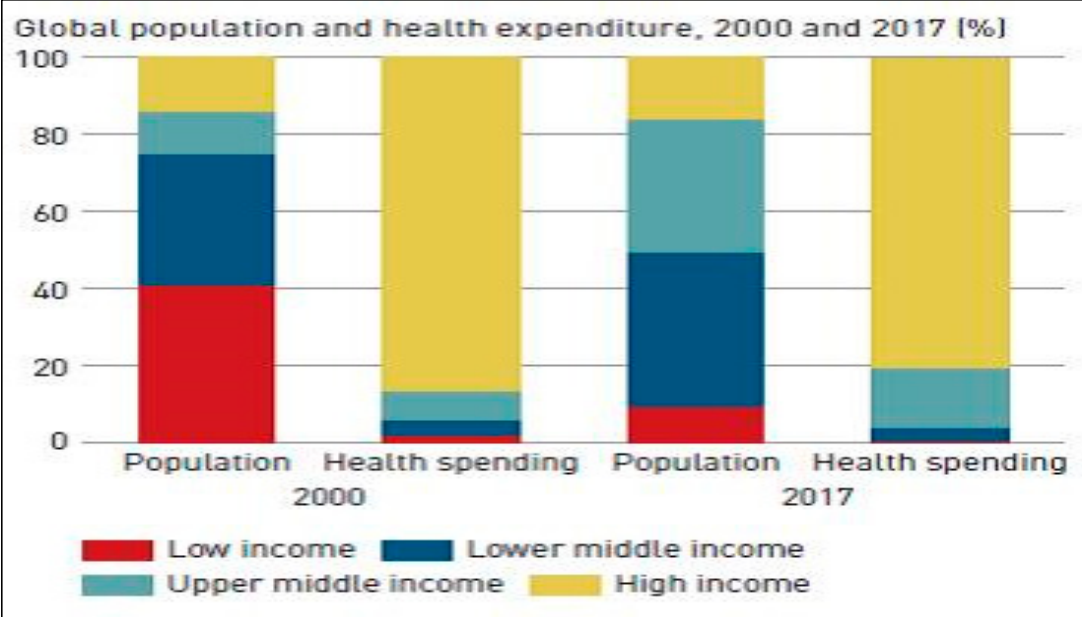

Figure 4. Global population and health expenditure 2000-2017 (\%). Source: WHO (WHO 2019).

Notwithstanding this converging pattern, the pattern of global health spending remains highly inequitable; for example, health spending as a share of GDP grew consistently in both lower middle and upper middle income countries, but larger discrepancies exist. In low income countries, health spending was only US\$41 a person in 2017 compared with US\$2937 in high income countries. Discrepancies in spending are associated with differences in wealth, with high income countries devoting a greater share of their income to health than low income countries, but even this has proved ineffective at providing pandemic preparedness and resilience.

5.2. Testing Preparedness \#2: Although There Is a Global Pattern of Rising Real Per Capita Health Spending, Controlled Mainly by Public Expenditure rather than Out-of-Pocket Costs, This Is not an Indicator of Pandemic Preparedness

Figure 5 shows that $60 \%$ of global spending on health came from public spending in 2017, compared with 56\% in 2000, a $4.3 \%$ annual increase. Despite this, decelerating growth is evident from $4.9 \%$ a year between 2000 and 2010 to $3.4 \%$ between 2010 and 2017. This important trend requires monitoring in order to progress towards universal health coverage and sustainability, especially in times of pandemic.

As shown in Figure 6, although out-of-pocket spending per capita increased between 2000 and 2017, the rate of increase was slower than government spending; therefore, it has consistently declined across all income groups. Out-of-pocket spending per capita in low income countries increased from 
US\$14 in 2000 to US\$18 in 2017, but because of increased public spending, these countries experienced an average decline in the share of out-of-pocket spending from 50\% of total spending in 2000 to $41 \%$ in 2017.

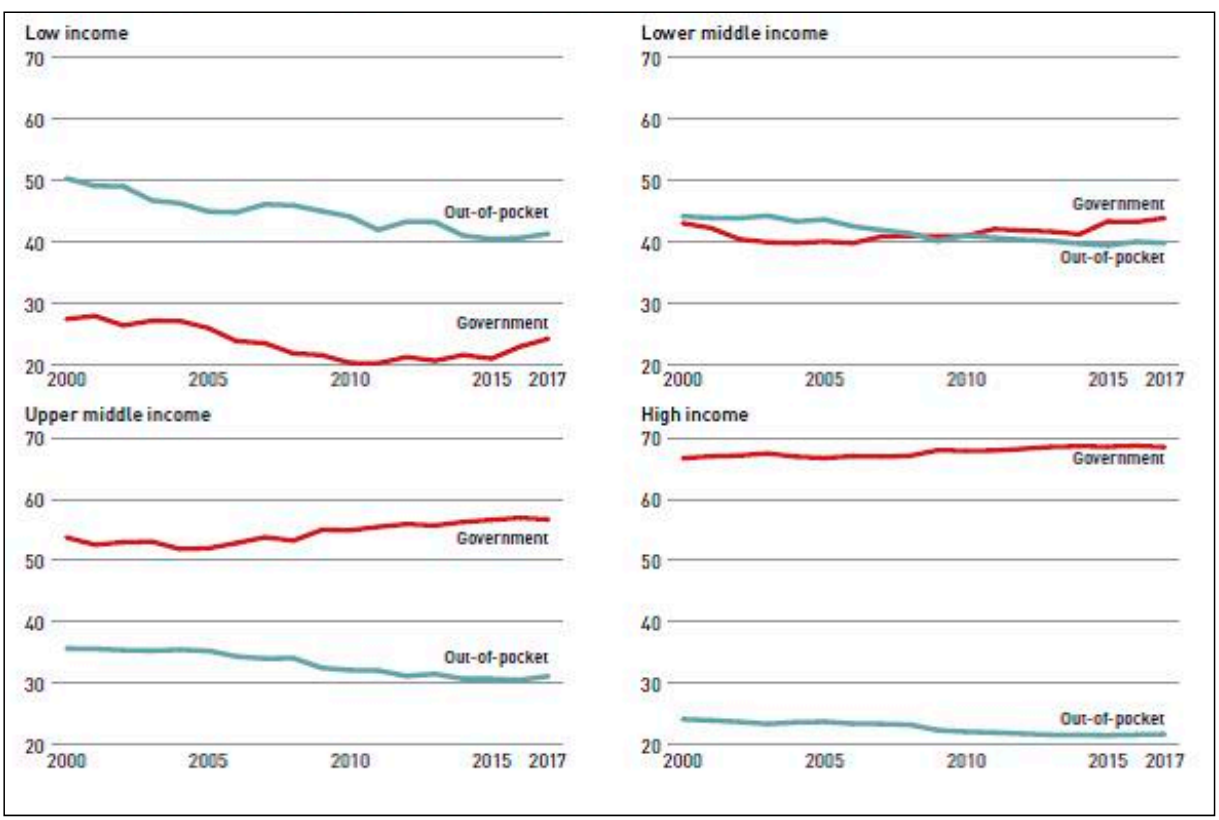

Figure 5. Less resilient out-of-pocket share of health spending 2000 to 2017 (\%). Source: WHO (WHO 2019).

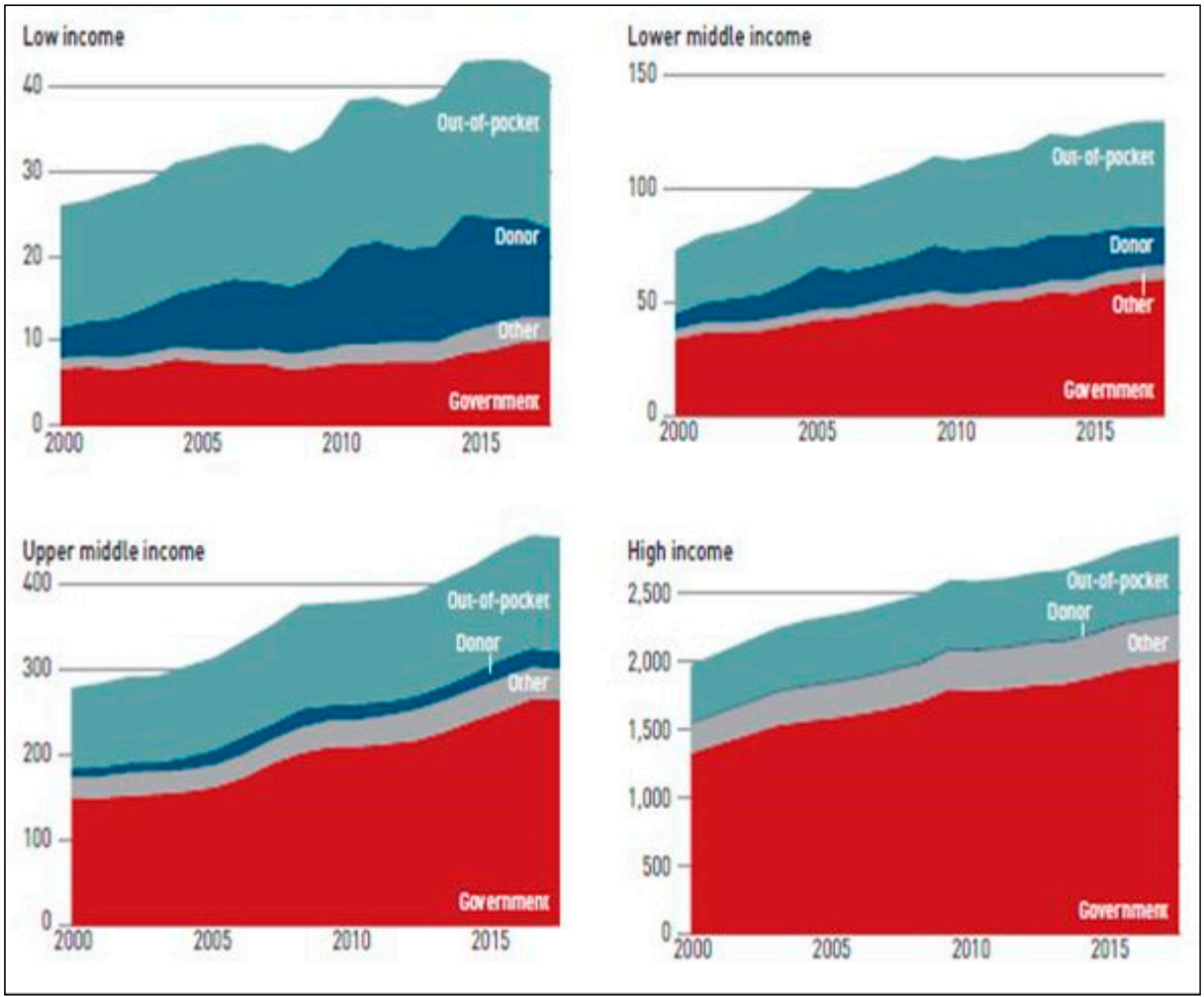

Figure 6. Health spending per capita by source and income group, 2000-2017 (constant 2017 \$ US). Source: WHO (WHO 2019). 
5.3. Testing Preparedness \#3: High Public Healthcare Expenditure Is Expected to Remain High Post-Crisis Regardless of Whether Healthcare Spending Is Efficiently Distributed or not

Government spending during times of crisis can be explained by the Peacock-Wiseman displacement hypothesis. British economists Alan Peacock and Jack Wiseman observed that government spending in social crises steps up in a sequential manner until it reaches a plateau from which it never returns to the original level (Henrekson 1990). The divergence between the desired level of government spending and tolerable levels of public tax is narrowed. Government expenditure in times of crisis could be considered an obligation to support disadvantaged groups through unemployment benefit; medical insurance; and, in the case of wars, veteran support. At the end of any social crisis, the tax imposed remains, allowing governments to permanently fund spending at a higher level than before the crisis.

Taking it a step back, pre-COVID-19, rapid economic growth and an increase in government revenue does not always translate into a larger budget share for healthcare, indeed, in some cases, the public budget share spent on health declines in countries where governments use the additional revenue for other priorities. As shown in Figure 7, real GDP per capita increased 1.6 times globally from 2000 to 2017, reflecting expectations of higher quality health services. In other words, governments were expected to increase their expenses to satisfy the expectations of individuals in terms of technology, quality, and service. Figure 8 shows that, on average, countries had a 2 percentage point increase in government spending as a share of GDP, while one-third had a public spending decline as a share of GDP despite their growing economies. With the current pandemic, not all fast growing economies have fully realized their potential to foster higher tax revenues, but this will probably reach a peak in the crisis.

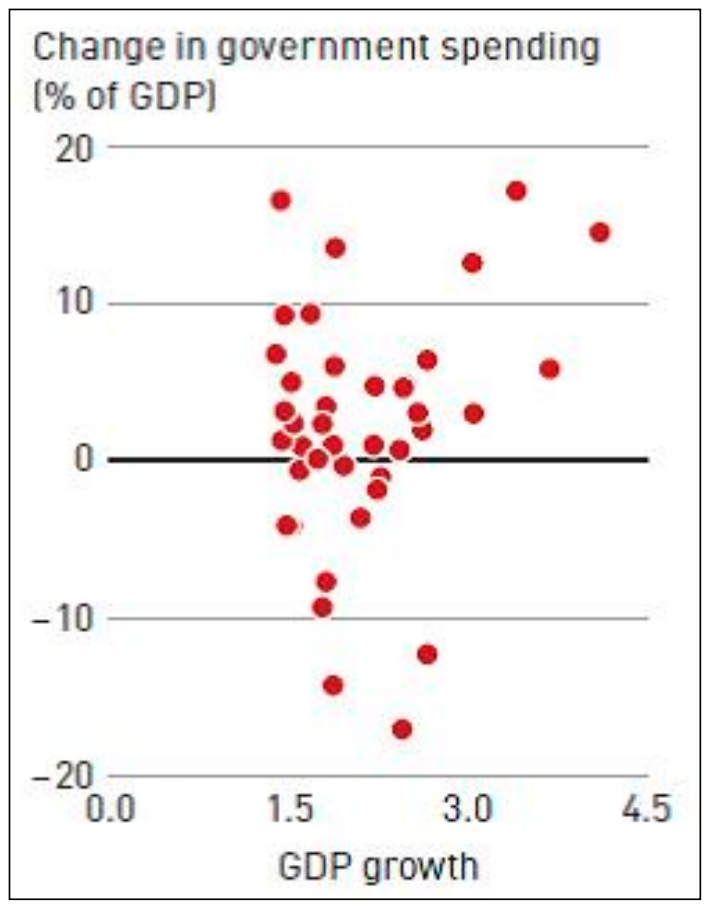

Figure 7. Change in government spending (\% of GDP) 2000 to 2017 WHO (WHO 2019). 


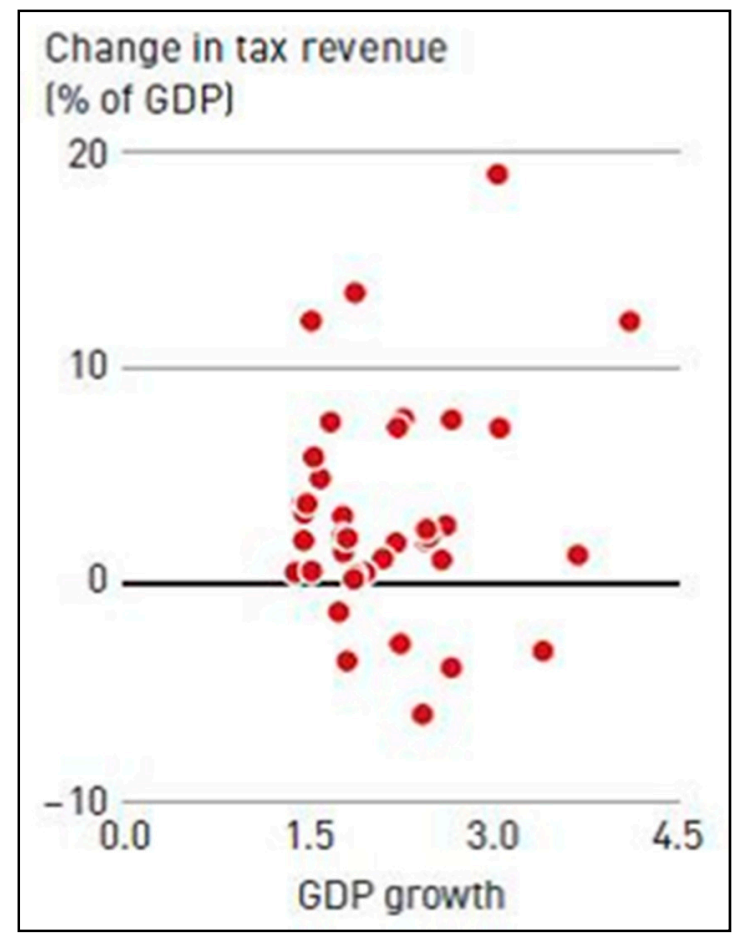

Figure 8. Change in tax revenue (\% of GDP) 2000 to 2017 WHO (WHO 2019).

5.4. Testing Preparedness \#4: Evidence of Global Inequality in Global Health Spending Is a Drawback for Pandemic Preparedness

Variations in health spending per capita are shown in Figure 9. North America and Western Europe have the highest levels of spending and West, Central, and East Africa have the lowest. There are large variations in spending among countries with similar income patterns, for example, Brazil spends more than twice as much per capita as Turkey, although they have similar GDPs per capita. The question here is, if public spending on health was already effective, as shown in Figures 7 and 8, despite the inequalities, what has prevented the containment of COVID-19, specifically in developed countries?

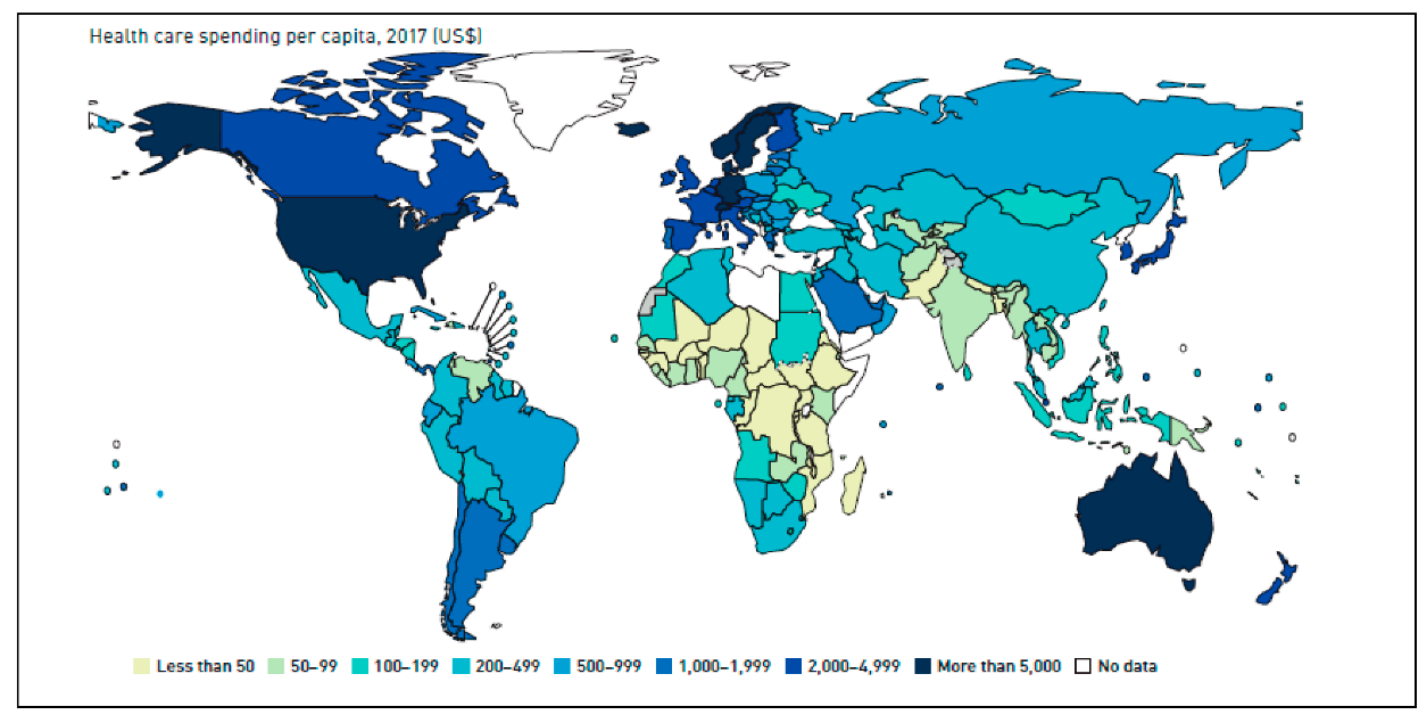

Figure 9. Variations in health spending per capita 2017 (US\$). Source: WHO (2019). 
Summary of existing unpreparedness indicators and low resilience to pandemics

1. There should be a redirection of global spending patterns targeting health as a national security priority.

2. The perception that a high real GDP per capita is an indicator of high health expenditure is questionable.

3. The perception that relatively fast global health spending increases, compared with real GDP growth rates, is not an indicator of pandemic preparedness or an indicator of achieving sustainable health.

4. Although there is a global pattern of rising real per capita health spending, based on public expenditure rather than out-of-pocket spending, this is not an indicator of pandemic preparedness or resilience.

5. Inequality in global health spending is a big drawback for resilience to pandemics.

\section{Transitioning into Pandemic Awareness Indicators via Public Expenditure}

\subsection{Awareness Indicator \#1: Time Response to Pandemic}

Despite the high rankings of the global health security (GHS) ${ }^{1}$ index, COVID-19 has shown that national healthcare systems have gaps in terms of resilience and preparedness. Global preparedness for both epidemics and pandemics is measured out of 100, with 40.2 being the average score. Although the USA ranked \#1 with a GHS index of 83.5 and the United Kingdom ranked \#2 with a GHS index score of 77.9, their ranking is not necessarily an indicator that their public spending on health has ensured preparedness and/or proved effectiveness. In fact, as explained below, both the USA and United Kingdom experienced delayed efforts in dealing with the pandemic (GHS Index Reports 2020).

\subsubsection{The Relationship between Delayed Efforts and Pandemic Preparedness for High GHS} Index Countries

Although the United Kingdom is ranked \#2 in GHS index with health expenditure of $9.8 \%$ of GDP and healthcare fully funded and delivered by the government, the delayed response before running the pandemic preparedness plan, opting against mass closure, heightened COVID-19's effects (Lafortune 2020). This delayed effort tested the healthcare system's absorptive capacity, with a high number of people infected, a lack of protective equipment, and an urgent need for ventilators, highlighting the importance of investment in both inputs and outputs.

For the same reasons, that is, delays in implementing pandemic preparedness schemes and lockdown, the United States healthcare system, with its combination of public and private funding sources, had difficulty ramping up its hospital capacity. Some states, such as California, were able to curb the virus by implementing pandemic preparedness plans quickly (Lafortune 2020). Other external factors that force governments to target their spending on defending against threats rather than pandemics include political and national security risks. To enhance compliance with international health standards, filling the gaps in health system capacity, critical to pandemic response, is essential.

\subsubsection{South Korean and Taiwanese Experiences from Past Epidemics Ensuring a Fast Response to Pandemic}

South Korea has made previous national efforts aimed at pandemic preparedness, having learned from its experience with 2015 Middle East Respiratory Syndrome (MERS) outbreak. It took action that made it resilient to the COVID-19 pandemic. With its infectious disease surveillance system, widespread testing, tracing, isolation of cases, government advisories, and physical distancing, the pandemic was contained with no lockdown, unlike in other countries (Stutzman et al. 2020). South Korea

1 The global health security (GHS) index is the first comprehensive benchmark for health security and related national capabilities to track the key factors of health preparedness of nations. It was introduced by the Nuclear Threat Initiative (NTI) and the Johns Hopkins Center for Health Security (JHU) and developed by the Economist Intelligence Unit (EIU). 
has proven the importance of public-private collaboration in the healthcare sector. Public funding targeted towards pandemic preparedness is a necessary long-term investment, essential for health security and international cooperation. The national health insurance programme covers most citizens, and healthcare services are delivered and run by the private sector. The government programme is heavily dependent on cost-sharing, with patients' out-of-pocket costs constituting 34\% of healthcare expenditure (Stutzman et al. 2020).

Although overpopulated and urban, the Taiwanese government quickly put an effective epidemic response plan in place, devised following the 2003 outbreak of the Severe Acute Respiratory Syndrome (SARS) (Universal Public Health 2020). Cell phone apps including body heat sensors and other technological solutions were used along with enforced quarantine in cases of infection. Taiwan also took it a step further, and banned the export of medical supplies and increased and nationalized the production of face masks.

\subsection{Awareness Indicator \#2: Efficient Resource Allocation and Capital Investment}

Awareness of the Basic Economic Problem: How to Manage Scarce Resources in Healthcare Systems to Provide Resilience

These are uncertain times, and to ensure preparedness and resilience, healthcare systems are expected to manage their scarce resources in the most efficient way, minimizing waste and ensuring sustainability. Priority setting is the first step, comparing marginal benefits to marginal costs, avoiding ineffective strategies, and reordering health needs (Chalkidou and Krubiner 2020). Priority setting is summarized below in a sequential four phase order, starting with Table 3 (building resilience and ensuring labor safety), Table 4 (relaxing collective social distancing orders), Table 5 (restoring 80\% of total workforce) and Table 6 (mobilizing a full pandemic resilient economy). Undertaking the six pandemic preparedness phases given below and injecting public funding into the four phases of building a pandemic resilient economy, previously discussed, cannot be done unless public funding of research is achieved as a first step.

Table 3. Phase One: Stabilization of Essential Sectors: Building Resilience and Ensuring Labor Safety.

\begin{tabular}{|c|c|c|}
\hline Phase One & & Public Expenditure and Suggested Targets \\
\hline \multirow{5}{*}{$\begin{array}{c}\text { Stabilization of essential sectors by } \\
\text { building resilience and ensuring } \\
\text { labour safety. }\end{array}$} & 1. & Building capacity to safely treat COVID-19 patients and other patients. \\
\hline & 2. & $\begin{array}{l}\text { Providing testing supplies with a daily production increase to accommodate } \\
\text { new patient conditions. }\end{array}$ \\
\hline & 3. & $\begin{array}{l}\text { Investing in local production of inputs and outputs in both running systems } \\
\text { and absorptive capacities. This step is essential before a pandemic as a } \\
\text { preparedness scheme, and during the pandemic as an emergency plan that } \\
\text { needs to be implemented quickly. }\end{array}$ \\
\hline & 4. & $\begin{array}{l}\text { Mobilizing the first part of the labour force into the economy, ensuring } \\
\text { their safety. }\end{array}$ \\
\hline & 5. & $\begin{array}{l}\text { Injecting public funding into research in order to facilitate the discovery and } \\
\text { production of vaccines. }\end{array}$ \\
\hline
\end{tabular}

Source: the author.

Table 4. Relaxation of Collective Social Distancing Orders.

\begin{tabular}{ccl}
\hline Phase Two & & Public Expenditure and Suggested Targets \\
\hline $\begin{array}{c}\text { Relaxation of collective social } \\
\text { distancing orders. }\end{array}$ & 1. & $\begin{array}{l}\text { Ensuring the production of testing and safety equipment to incrementally } \\
\text { absorb more labour into the economy. }\end{array}$ \\
$\begin{array}{l}\text { Financing social awareness campaigns by directing citizens into universal } \\
\text { mask wearing, with high hygiene standards. }\end{array}$
\end{tabular}


Table 5. Providing Access to Testing Supplies, Restoration of $80 \%$ of Workforce.

\begin{tabular}{cll}
\hline Phase Three & & Public Expenditure and Suggested Targets \\
\hline $\begin{array}{c}\text { Providing access to testing } \\
\begin{array}{c}\text { supplies, thereby restoring more } \\
\text { than } 80 \% \text { of the workforce. }\end{array}\end{array}$ & $\begin{array}{l}\text { 1. } \\
\text { 2. }\end{array}$ & $\begin{array}{l}\text { Integrating more workers into the workforce by incremental local investment } \\
\text { in testing, safety measures, and equipment. } \\
\text { Investing in research and in building national infectious disease forecasts. } \\
\text { Investing in the establishment of social service agencies, which integrate less } \\
\text { vulnerable populations into the pandemic economy. }\end{array}$ \\
\hline
\end{tabular}

Source: the author.

Table 6. Full Mobilization of Pandemic Resilient Economy.

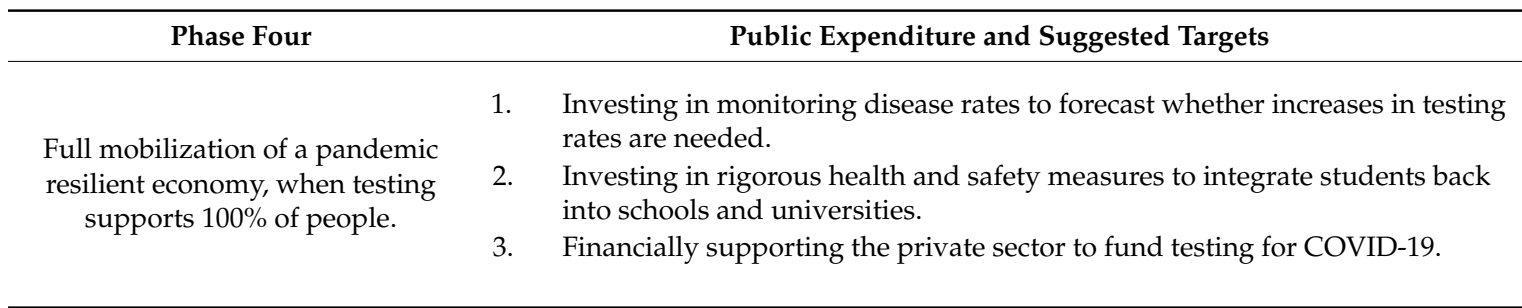

Source: the author.

\subsection{Awareness Indicator \#3: SDG Awareness and Implementation}

6.3.1. Netherlands: Public Expenditure towards a Doughnut Economy, Integrating Sustainability through SDGs

Similar to South Korea and Taiwan, the Dutch government, which covers healthcare costs through taxation, equitable insurance payments, and out-of-pocket payments, responded quickly to the pandemic, by deciding on a partial lockdown (Kusmer 2020). A new pragmatic way of thinking post-COVID-19 encouraged a change in governmental priorities to a focus on health and community rather than economic growth. GDP is no longer a proxy for societal success, and the coronavirus crisis is a perfect time to re-evaluate economic systems by exploring alternatives to growth-oriented economic policy. Amsterdam is the first city in the world to make progress towards "doughnut economics", an economic framework created by Kate Raworth in 2012, where interdisciplinary values such as social interaction, health, and solidarity integrate with one another, with the doughnut acting as a compass for human welfare and prosperity (Kusmer 2020). In terms of pandemic preparedness, the hole in the doughnut represents scarce social resources such as safe housing, good quality food, and fresh water.

6.3.2. Egypt: A Strong Strategy of Embedding SDGs with Already Existing Preparedness Measures for Dealing with COVID-19

The main challenge Egypt faced in the COVID-19 pandemic was the highly populated nature of the country and the fast spread of the disease. This was overcome by effectively implementing a preparedness plan that integrated the SDGs and collaboration among the ministries. Allocations of healthcare sector spending for the fiscal year 2020/2021 are estimated to equal EGP258 billion (Ministry of Finance-Egypt 2020), a 46\% increase compared with 2019/2020. According to Rania Al Mashaat, Minister of International Cooperation, Egypt's healthcare system preparedness and governance proved successful, in line with WHO measures of early detection, laboratory testing, isolation, contract tracing, and referral of patients. Additional governmental efforts to put in place human and financial resources and strong disease surveillance systems controlled sporadic clusters of cases before they spread. Informational updates on the COVID-19 situation and cases, as well as televised information about how to protect oneself from the virus, proved effective.

Egypt's Ministry of International Cooperation integrated three Ps-people at the core, projects in action, and purpose as the driver, with integration of the SDGs at an international collaborative level to ensure sustainable health. For instance, collaboration between Egypt and the International Fund 
for Agricultural Development IFAD analysed the impact of COVID-19 on food security, addressing SDG1 and SDG2, the importance of the agricultural sector, local production, and solutions offered by multilateral institutions. This helped put targeted plans in place for public expenditure at the macro level.

\section{Scenarios to Consider: A Different Mind-Set}

7.1. Scenario One: What Happens if Health Institutions Transition Themselves from Health Insurance Models to Health Financing Models, in Order to Contain Pandemic Effects by Being Prepared?

The effects of COVID-19 have called into question the main role of health institutions and the nature of public spending patterns, raising this issue of whether health institutions should move from health insurance models to health financing models. The growth of public health expenditure targeted towards social health insurance (SHI) is questionable even in the steady state (no pandemic) with regards to either progress towards universal health coverage or covering health services for the population. According to the WHO (2017), the implementation of SHI gradually increased from 113 countries in 2000 to 126 in 2017. SHI spending transactions accounted for more than $5 \%$ of public spending on health in 97 countries. For low income countries, the share of SHI varied from 1 to $2 \%$; for lower middle income countries, from $4.5 \%$ to $8.5 \%$; and for upper middle income countries, from $16 \%$ to $20 \%$ (WHO 2017). In other words, there is an urgent need to restructure health institution objectives to insure health financing is based on sustainable health factors rather than insurance models.

Forecasts of healthcare spending growth after the pandemic (with rising prices and a rebound in spending) are not the focus now, rather it is analysing the impact of the pandemic on the allocation of resources to show tangible results and preparedness schemes (Chernew 2020). Barroyl et al. (2020) recommend putting sufficient public funding in place for a comprehensive response that would bolster public spending on the health system and budgetary practice that involves immediate spending within existing budgets for the COVID-19 response, sustaining strong health systems including healthcare professionals, accessible clinics, commodities, and working supply chains.

\subsection{Scenario Two: How Will COVID-19 Restructure Global Public Health Spending Values and Visions?} The Importance of Investment and Preparedness

The COVID-19 pandemic has led to the implementation of special financing arrangements that support resilience and preparedness before, during, and between pandemics. In simple terms, countries seeking to enhance their preparedness use the WHO's joint external evaluation mechanism to identify their current state and possible needs. The mechanism evaluates each country's overall preparedness in four main areas: (1) prevention (national legislation, policy, financing, international health regulation coordination, communication, and advocacy); (2) detection (through national laboratory systems, real-time surveillance, reporting, and workforce development); (3) response (including emergency response operations, linking public health and security authorities, medical countermeasures, personnel deployment, and risk communication); and (4) other related hazards and points of entry (IISD 2020).

\subsection{Scenario Three: Could Collective Global Collaboration Help Build Pandemic Preparedness and Resilience?}

A shared system for adopting local and global lessons about what has worked in the past and what has proven insufficient for containing the spread of the disease is essential. This would prevent a lack of information, adverse selection, and moral hazards, and allow for the development of sustainable region-wide policies that guide efficient resource allocation. Collective engagement at the local level among decision-makers, in national and local governments, service delivery, supply chain channels, universities, and research centres, is required. To avoid jeopardizing key health gains by prioritizing health and its sustainability, governments must mitigate the diversion of resources during crises. 


\section{Conclusions}

Challenges remain, based on human nature, because the willingness to expend time and energy does not extend to an emergency such as a pandemic. This paper raises awareness of the importance of formulating pandemic preparedness and implementing it rapidly before, during, and after the crisis. Public health expenditure, a facilitator of pandemic preparedness, coupled with resilient healthcare systems, along with traditional factors and the time element of quick response to the pandemic, are measures of sustainable health and the United Nations Sustainable Development Goals. Investment in national healthcare ensures efficient resource allocation. The policy recommendations call for restructuring public expenditure to expand the absorptive capacity of healthcare institutions, eventually leading to sustainability and universal health insurance. The specific policy recommendations made are as follows:

Policy \#1: A restructuring of awareness, to see healthcare as a key component of national security and a public expenditure priority.

Policy \#2: A restructuring of public spending on healthcare including investment in pandemic preparedness and resilience, efficient resource allocation of input and output investment schemes, nationalizing the production of healthcare equipment, and flexibly widening the absorptive capacity of the healthcare sector.

Policy \#3: A retransformation of health public expenditure into services that add value to individual sustainable health, rather than provide health insurance, which has proved inadequate even if progressing towards universal health coverage.

Policy \#4: A re-examination of revenue spending patterns coming from the healthcare sector including whether revenue actually feeds into healthcare and human capital investment.

Policy \#5: A reanalysis of the importance of the time element in responding to pre-planned emergency action plans when faced with a pandemic and a re-examination of global health architecture to promote sustainable investment in emergency preparedness.

Policy \#6: A leap forward plan, learning from the crisis and building better systems for implementing and integrating sustainable health through SDGs.

Further research could include an empirical analysis of public expenditure patterns and their relationship to pandemic preparedness across countries.

Funding: This research did not receive any specific grant from funding agencies in the public, commercial, or not-for-profit sectors.

Conflicts of Interest: The author declares no conflict of interest.

$\begin{array}{ll}\text { Abbreviations } \\ \text { CDC } & \text { Centre for Disease Control and Prevention } \\ \text { COVID-19 } & \text { Coronavirus Disease 2019 } \\ \text { ESD } & \text { Education for Sustainable Development } \\ \text { GDP } & \text { Gross Domestic Product } \\ \text { GHS Index } & \text { Global Health Spending Index } \\ \text { IFAD } & \text { International Fund for Agricultural Development } \\ \text { IISD } & \text { International Institute for Sustainable Development } \\ \text { MDGs } & \text { Millennium Development Goals } \\ \text { OECD } & \text { Organization for Economic Co-operation and Development Countries } \\ \text { SDGs } & \text { Sustainable Development Goals } \\ \text { SHI } & \text { Social Health Insurance } \\ \text { UK } & \text { United Kingdom } \\ \text { UNESCO } & \text { United Nations Educational, Scientific, and Cultural Organization } \\ \text { USA } & \text { United States of America } \\ \text { WHO } & \text { World Health Organization }\end{array}$




\section{References}

Barredo, Lauren. 2020. Implications of COVID-19 for Public Health and the SDGs. New York: Sustainable Development Solutions Network. Available online: https://www.unsdsn.org/covid-19-webinar (accessed on 5 March 2020).

Barroyl, Hélène, Ding Wang, Claudia Pescetto, and Joseph Kutzin. 2020. How to Budget for COVID-19 Response? A Rapid Scan of Budgetary Mechanisms in Highly Affected Countries. Social Health Protection Network. Available online: https://p4h.world/en/node/8821 (accessed on 27 March 2020).

Becker, Gary S. 1964. Human Capital: A Theoretical and Empirical Analysis with Special Reference to Education. New York: Columbia University Press.

Bloom, David E., David Canning, Linlin Hu, Yuanli Liu, Ajay Mahal, and Winnie Yip. 2010. The Contribution of Population Health and Demographic Change to Economic Growth in China and India. Journal of Comp Economics 38. [CrossRef] [PubMed]

Centre for Disease Control and Prevention Official. 2020. Available online: https://wwwnc.cdc.gov/ (accessed on 27 May 2020).

Chernew, Michael E. 2020. How to Read National Health Expenditure Projections in Light of COVID-19: Uncertain Long-Run Effects but Changes for All. Health Affairs. Available online: https://www.healthaffairs.org/do/10. 1377/hblog20200417.842451/full/ (accessed on 22 April 2020).

Day, Kathleen Mary, and Julie Tousignant. 2005. Health Spending, Health Outcomes, and Per Capita Income in Canada: A Dynamic Analysis. Ottawa: Department of Economics, University of Ottawa.

Di Matteo, Livio, and Rosanna Di Matteo. 1998. Evidence on the determinants of Canadian provincial government health expenditures: 1965-91. Journal of Health Economics 17: 211-28. [CrossRef]

Dormont, Brigitte, Michel Grignon, and Hélène Huber. 2006. Health expenditure growth: Reassessing the threat of ageing. Health Economics 15: 947-63. [CrossRef] [PubMed]

Dreger, Christian, and Hans-Eggert Reimers. 2005. Health Care Expenditures in OECD Countries: A Panel Unit Root and Co-integration Analysis (January 2005). IZA Discussion Paper No. 1469. Available online: https://ssrn.com/abstract=651985 (accessed on 4 July 2020).

El-Erian, Mohamed A. 2020. COVID-19 and the Rise of the Pandemic Economy. Channel New Asia. Available online: https://www.channelnewsasia.com/news/commentary/COVID-19-coronavirus-fiscal-stimulus-packagebank-recession-jobs-12605646 (accessed on 15 April 2020).

Gerdtham, Ulf-G., Jes Søgaard, Bengt Jönsson, and Fredrik Andersson. 1992. A pooled cross section analysis of the health care expenditures of the OECD countries. In Health Economics Worldwide. Edited by P. Zweifel and H.E. Frech. Boston: Kluwer Academic Publishers, pp. 287-310.

GHS Index Reports. 2020. GHS Index Report 2020. Available online: https://www.ghsindex.org/ (accessed on 15 May 2020).

Grays, D. 2020. The Lasting Impacts of COVID-19 on the Health Care System. Texas A\&M University Health Science. Available online: https://today.tamu.edu/2020/04/22/the-lasting-impacts-of-covid-19-on-the-healthcare-system/ (accessed on 17 May 2020).

Grigoli, Francesco, and Javier Kapsoli. 2013. Waste Not, Want Not: The Efficiency of Health Expenditure in Emerging and Developing Economies. International Monetary Fund, Working Paper 13/187. Washington: IMF.

Gudi, Sai Krishna, and Komal Krishna Tiwari. 2020. Preparedness and lessons learned from the novel coronavirus disease. International Journal of Occupational and Environmental Medicine 11: 108-12. [CrossRef] [PubMed]

Gupta, Indrani, and Arup Mitra. 2004. Economic growth, health, and poverty: An exploratory study for India. Development Policy Review 22: 193-206. [CrossRef]

Henrekson, Magnus. 1990. Peacock and Wiseman's displacement effect: A reappraisal and a new test. European Journal of Political Economy 6. Available online: https://ssrn.com/abstract=2174657 (accessed on 20 April 2020).

Howitt, Peter, and David Mayer-Foulkes. 2005. R\&D, implementation, and stagnation: A Schumpeterian theory of convergence clubs. Journal of Money, Credit and Banking 37: 147-77.

Igoe, Michael, and Vince Chadwick. 2020. After the Pandemic: How will COVID-19 Transform Global Health and Development? Devex. Available online: https://www.devex.com/news/after-the-pandemic-how-will-covid19-transform-global-health-and-development-96936 (accessed on 17 May 2020).

IISD (International Institute for Sustainable Development). 2020. International Institute for Sustainable Development Report 2020. Winnipeg: IISD.

Javadipour, S. 2005. Studying the Impact of Health Expenditures on Economic Growth. Masters Thesis submitted to the Department of Economy, Tabatabaee University, Tehran, Iran. 
$\mathrm{Ke}, \mathrm{Xu}$, Priyanka Saksena, and Alberto Holly. 2011. The Determinants of Health Care Sector, a Country Level Panel Data Analysis. World Health Organization: Results for Development Institute. Available online: https://www.who.int/health_financing/documents/report_en_11_deter-he.pdf (accessed on 1 May 2020).

Klein, Ezra. 2020. I've Read the Plans to Reopen the Economy. They're Scary. There Is no Plan to Return to Normal. Vox. Available online: https://www.vox.com/2020/4/10/21215494/coronavirus-plans-social-distancing-economyrecession-depression-unemployment (accessed on 25 April 2020).

Kusmer, Anna. 2020. Amsterdam's Coronavirus Recovery Plan Embraces Doughnut Economics for People and the Planet. The World. Available online: https://www.pri.org/stories/2020-05-11/amsterdam-s-coronavirus-recoveryplan-embraces-doughnut-economics-people-and (accessed on 20 May 2020).

Lafortune, Guillaume. 2020. How much Do We Know about Countries Preparedness to Respond to Pandemics? Insights from Two Country-Level Indices. Sustainable Development Network Solutions. Available online: https://www.unsdsn.org/how-much-do-we-know-about-countries-preparedness-to-respond-topandemics-insights-from-two-country-level-indices (accessed on 27 May 2020).

Mendelson, Sarah. 2020. The Virus and the Global Goals: What Could COVID-19 Mean for Sustainable Development. Joint SDG Fund. Available online: https://www.jointsdgfund.org/article/virus-and-globalgoals-what-could-covid-19-mean-sustainable-development (accessed on 20 May 2020).

Ministry of Finance-Egypt. 2020. Available online: http://www.mof.gov.eg/english/pages/home.aspx (accessed on 20 May 2020).

Murthy, Vasudeva NR, and Albert A. Okunade. 2009. The core determinants of health expenditure in the African context: Some econometric evidence for policy. Health Policy 91: 57-62. [CrossRef] [PubMed]

Musgrove, Philip, Riadh Zeramdini, and Guy Carrin. 2002. Basic patterns in national health expenditure. Bulletin of the World Health Organization: The International Journal of Public Health 80: 134-42. [PubMed]

Newhouse, Joseph P. 1992. Medical care costs: How much welfare loss? The Journal of Economic Perspectives 6: 3-21. [CrossRef] [PubMed]

Potrafke, Niklas. 2010. The growth of public health expenditures in OECD countries: Do government ideology and electoral motives matter? Journal of Health Economics 29: 7979-810. [CrossRef] [PubMed]

Rivera, Berta, IV, and Luis Currais. 1999. Economic growth and health: Direct impact or reverse causation? Applied Economics Letters 6: 761-64. [CrossRef]

Sarah, Mendelson. 2020. Sustainable Growth and COVID-19. Global Dashboard Organization. Available online: https://www.globaldashboard.org/2020/04/07/the-virus-and-the-global-goals-what-could-covid-19mean-for-sustainable-development/ (accessed on 3 May 2020).

Scherer, Peter, and Marion Devaux. 2010. The Challenge of Financing Health Care in the Current Crisis: An Analysis Based on the OECD Data. OECD Health Working Papers, 49. Paris: OECD Publishing. [CrossRef]

Stutzman, Hayley, Angela E. Micah, and Joseph L Dieleman. 2020. Governance: Funding Pandemic Preparedness: A Global Public Good. Council on Foreign Relations. Available online: https://www.thinkglobalhealth.org/ article/funding-pandemic-preparedness-global-public-good (accessed on 30 April 2020).

UN (United Nations). 2020. United Nations Report: Shared Responsibility, Global Solidarity. Responding to the Socio-Economic Impacts of COVID-19 March 2020. New York: UN.

Universal Public Health. 2020. Taiwan and South Korea COVID19 Response, a Lesson for All. Ferney-Voltaire: Public Services International. Available online: https://publicservices.international/resources/news/taiwan--southkorea-covid-19-response-a-lesson-for-all?id=10683\&lang=en (accessed on 20 April 2020).

Van Zon, Adriaan, and Joan Muysken. 2001. Health and endogenous growth. Journal of Health Economics 20: 85-169. [CrossRef]

WHO. 2017. WHO, World Health Report 2017: Health Systems Financing: The Path to Universal Coverage. Geneva: WHO. Available online: https://www.who.int/whr/2010/en (accessed on 1 April 2020).

WHO. 2019. WHO: Global Spending on Health: A World in Transition. Geneva: WHO.

Yeung, Jessie. 2020. Ten Lessons from Asia on How to Live with a Coronavirus Outbreak. CNN. Available online: www.cnn.com/2020/03/04/asia/coronavirus-lessons-from-asia-intl-hnk-scli/index.html (accessed on 20 April 2020).

(C) 2020 by the author. Licensee MDPI, Basel, Switzerland. This article is an open access article distributed under the terms and conditions of the Creative Commons Attribution (CC BY) license (http://creativecommons.org/licenses/by/4.0/). 